Article

\title{
The Impact of Moss Species and Biomass on the Growth of Pinus sylvestris Tree Seedlings at Different Precipitation Frequencies
}

\author{
Babs M. Stuiver *, David A. Wardle, Michael J. Gundale and Marie-Charlotte Nilsson \\ Department of Forest Ecology and Management, Swedish University of Agricultural Sciences, \\ SE 90183 Umeå, Sweden; E-Mails: David.Wardle@slu.se (D.A.W.); \\ Michael.Gundale@slu.se (M.J.G.); Marie-Charlotte.Nilsson@slu.se (M.-C.N.) \\ * Author to whom correspondence should be addressed; E-Mail: Babs.Stuiver@slu.se; \\ Tel.: +46-90-786-8100; Fax: +46-90-786-8125.
}

Received: 9 May 2014; in revised form: 13 July 2014 / Accepted: 21 July 2014 /

Published: 6 August 2014

\begin{abstract}
Boreal forests are characterized by an extensive moss layer, which may have both competitive and facilitative effects on forest regeneration. We conducted a greenhouse experiment to investigate how variation in moss species and biomass, in combination with precipitation frequency, affect Pinus sylvestris seedling growth. We found that moss species differed in their effects on seedling growth, and moss biomass had negative effects on seedlings, primarily when it reached maximal levels. When moss biomass was maximal, seedling biomass decreased, whereas height and above- relative to below-ground mass increased, due to competition for light. The effect that moss biomass had on seedling performance differed among the moss species. Hylocomium splendens and Polytrichum commune reduced seedling growth the most, likely because of their taller growth form. Seedlings were not adversely affected by Sphagnum girgensohnii and Pleurozium schreberi, possibly because they were not tall enough to compete for light and improved soil resource availability. Reduced precipitation frequency decreased the growth of all moss species, except $P$. commune, while it impaired the growth of seedlings only when they were grown with $P$. commune. Our findings suggest that changes in moss species and biomass, which can be altered by disturbance or climate change, can influence forest regeneration.
\end{abstract}


Keywords: boreal forest; bryophyte; climate change; competition; drought; facilitation; forest regeneration; interactions; moss depth; Scots pine

\section{Introduction}

Successful forest regeneration is crucial for the long-term sustainable management of boreal forest resources. A significant proportion of the forest floor in boreal forests is covered by mosses [1,2], and therefore, the rejuvenation of the stand is likely to be influenced by the properties of the moss layer. Rejuvenation of coniferous seedlings appears particularly difficult in forests with an abundant moss presence $[3,4]$, because mosses can outcompete seedlings for resources, such as light, space $[5,6]$ and nutrients $[7,8]$. Previous work has also shown that these negative effects of mosses on seedlings can vary depending on a variety of external factors, such as the degree of abiotic stress [6,9] and other site characteristics (e.g., the type of growth substrate beneath the mosses) [5,10]. Mosses may also positively affect tree seedlings indirectly by regulating moisture availability $[11,12]$, reducing temperature fluctuations [6,13], providing nutrients through enhancing litter decomposition rates [2,14] and potentially contributing to enhanced soil nitrogen levels via symbioses with $\mathrm{N}_{2}$-fixing cyanobacteria $[15,16]$. Given that mosses can have both positive and negative effects on tree seedlings, there is a need for an improved understanding of when these different effects emerge.

Even though mosses are widely abundant in boreal forests, the moss layer can be highly variable due to differences in moss species composition [17,18]. Moss species have many different morphological $[6,19]$ and physiological characteristics $[19,20]$ that can exert differential effects on seedlings. Moss species that are adapted to shady conditions with low evaporation rates generally have large shoots, which could potentially allow these species to be more effective light competitors, while also making these species more sensitive to desiccation [21]. In addition, moss species vary substantially in their water retention capacity [21,22], which can determine their desiccation rate and their recovery following drought [23,24]. Differences in water retention capacity among species may determine how severely the moss layer is impacted by drought, and this could, in turn, have consequences for seedling performance $[25,26]$. Further, due to their morphological and physiological characteristics, moss species differ in their capacity to intercept and retain nitrogen [2], as well as in their capacity to absorb phosphate [27]; however, it is unknown whether the impact of moss species on nutrient cycling is beneficial or detrimental to tree seedlings. Despite the large spatial and temporal variation in moss species composition that can occur in boreal forests, relatively few controlled experiments have explicitly evaluated how different moss species impact tree seedling growth. Most studies to date have been performed in natural environments [4,5] or have used dense transplanted moss cushions [20] and have, therefore, not specifically controlled for moss biomass and environmental factors.

Boreal moss layers also differ in moss biomass within the same species, which is determined by such properties as moss depth and shoot density. Moss biomass can by itself, and independently of moss species identity, also have effects on ecological processes that may have consequences for tree seedling growth and allocation patterns [28-30]. For instance, moss cushions of high biomass are 
likely to serve as stronger resource competitors with seedlings, thereby potentially diminishing seedling performance [31,32]. In addition to potential negative effects (i.e., competition), mosses may have several positive effects on tree seedlings that vary with depth and shoot density. As such, a high moss biomass will retain water better [11,21,33], which may reduce seedling desiccation in dry periods. The moist environment within mosses has also been shown to support $\mathrm{N}_{2}$-fixation and $\mathrm{N}$ mineralization processes $[14,15]$ that could potentially increase nutrient availability for seedlings. Those processes that can potentially stimulate tree seedlings can be negatively impacted by drought, especially when moss biomass is impaired to a level where the moss is less able to retain moisture. Understanding how drought impacts the moss layer and, thus, tree seedling regeneration is currently relevant in the boreal region, because it is predicted that climate warming will result in longer and more intense summer drought periods in the future [34-36]. There is therefore a need to understand whether climate change might cause a shift in the positive and negative impacts of mosses on tree seedling performance and the implications of this for future forest regeneration.

We investigated the effects of moss species, moss biomass and precipitation frequency on Pinus sylvestris seedlings in order to help explain variation in tree seedling performance in natural moss-dominated communities in Swedish boreal forests. The four moss species we considered were Pleurozium schreberi, Hylocomium splendens, Polytrichum commune and Sphagnum girgensohnii, which all occur commonly in these forests, but which differ in moisture retention [22,37], associative $\mathrm{N}_{2}$-fixation rates [15,38], morphology and growth form [39-41]. This study was conducted as a greenhouse mesocosm experiment that allowed us to test three hypotheses. First, we hypothesized that P. sylvestris seedling growth will be differentially affected by the four moss species, even when the biomass of the different mosses is the same, as a consequence of differences in the fundamental characteristics that may impact on seedling performance. Specifically, moss species with a high water retaining capacity or associative $\mathrm{N}_{2}$-fixation rate are more likely to have positive effects on seedling growth due to their ability to increase moisture retention and soil $\mathrm{N}$ availability. Further, mosses with a more detached growth form are expected to be less competitive against $P$. sylvestris seedlings for light and space. Second, we hypothesized that within each moss species, intermediate moss biomass on a per area basis will maximize seedling performance. This is because at intermediate biomass, there will be beneficial effects of moss in enhancing moisture and $\mathrm{N}$ input relative to when the moss is absent, but less competition relative to when the moss biomass is low. Third, we hypothesized that the presence of mosses will mediate the adverse effects of reduced precipitation frequency on the growth of $P$. sylvestris seedlings, but that this effect of mosses will vary according to moss species and the moss biomass present. Through exploring these three hypotheses, we will be able to better understand how the performance of $P$. sylvestris seedlings can be affected by moss species and biomass under contrasting moisture regimes and, therefore, the role that mosses may play in mediating tree seedling regeneration under contrasting precipitation regimes in the boreal forest. 


\section{Experimental Section}

\subsection{Moss Communities}

Shoots of $P$. schreberi, $H$. splendens, $P$. commune and $S$. girgensohnii were collected from three mixed P. sylvestris and Picea abies forest stands that were at least 80 years old at Vaksliden $\left(65^{\circ} 40.398^{\prime} \mathrm{N}, 18^{\circ} 53.501^{\prime} \mathrm{E}\right)$, Kulbäcksliden $\left(64^{\circ} 9.161^{\prime} \mathrm{N} 19^{\circ} 35.392^{\prime} \mathrm{E}\right)$ and Sävar $\left(64^{\circ} 9.161^{\prime} \mathrm{N}\right.$ $20^{\circ} 34.240^{\prime}$ E) in northern Sweden during September, 2011. Within these forest stands, we located dense monoculture patches of each moss species, from which we collected a total of thirty $15 \times 15-\mathrm{cm}$ sections, to be used in our greenhouse experiment. These sections were returned to the lab, and litter and non-target moss species were removed from each section. We destructively harvested a subset of the sections to compare their dry weights per unit area, which showed that the average moss biomass per unit area for all species was $618 \mathrm{~g}$ dry weight $\mathrm{m}^{-2}$ and did not differ significantly between species (ANOVA $F_{3,13}=0.832, p=0.504$, SuppLementary Information).

\subsection{Experimental Design}

In order to test our hypotheses, we set-up a greenhouse mesocosm experiment consisting of 204 freely-drained black plastic pots $(11 \mathrm{~cm} \times 11 \mathrm{~cm} \times 11 \mathrm{~cm})$, consisting of 12 moss free control pots, and the remainder covered with one of the four different moss species (i.e., 48 pots per species). The pots were lined with filter paper and filled with $3 \mathrm{~cm}$ of quartz sand and on top of this $5 \mathrm{~cm}$ of sieved humus collected at Kulbäcksliden. The highest initial moss biomass used in the pots was $500 \mathrm{~g}$ dry weight $\mathrm{m}^{-2}$ for each of the four species, which corresponds to approximately $80 \%$ of the biomass measured in monospecific moss cushions in the field when averaged across all species (see the Supplementary Information). We chose $80 \%$ to allow mosses to grow up to their maximum value (i.e., the measured field biomass) during the experiment. We estimated the dry:fresh weight ratio for each species (see Supplementary Information), enabling us to calculate the amount of fresh weight needed to be added to each pot to provide the desired dry weight.

The experiment was arranged as a full-factorial split-plot design arranged in 12 blocks. Each block contained one control pot with $0 \%$ moss cover and 16 pots representing all combinations of the four moss species and each of the following four moss biomass classes (MBC); 80\% (i.e., $500 \mathrm{~g} \cdot \mathrm{m}^{-2}$ ), $40 \%$ $\left(250 \mathrm{~g} \cdot \mathrm{m}^{-2}\right), 20 \%\left(125 \mathrm{~g} \cdot \mathrm{m}^{-2}\right)$ and $8 \%\left(50 \mathrm{~g} \cdot \mathrm{m}^{-2}\right)$ of the reference moss biomass value. The moss cushions were reconstructed within each pot by placing the necessary number of shoots, required to achieve the desired biomass levels, in each pot. Because the morphology of each moss species differed, the shoot density and height differed between the mosses for any given MBC. After pots were constructed in late November-early December, 2011, they were placed in the greenhouse to acclimatize for 12 days before newly germinated seeds were planted. Growing conditions in the greenhouse were set at a temperature of $16 \pm 2{ }^{\circ} \mathrm{C}, 120 \mu \mathrm{mol} \cdot \mathrm{s}^{-1} \cdot \mathrm{m}^{-2}$ radiation and an 18 -hour day length, as done in a previous experiment focused on mosses collected from this region [14]. Relative humidity was kept at $70 \% \pm 10 \%$, which is comparable to those values that occur in the field [42], with a fine spray system. After 12 days, each pot $(n=204)$ was planted with ten newly germinated $P$. sylvestris seeds, which were carefully placed on top of the humus layer, meaning that the seedlings started to grow below the moss layer when present. After 6 weeks (i.e., January, 2012), the least 
vigorous individuals were removed from each pot, leaving the three most vigorous individuals remaining. At the same time, we started two precipitation frequency treatments, i.e., ambient (watering every second day) and reduced (watering every sixth day). The treatments were assigned by randomly assigning half of the 12 blocks to each of the two precipitation frequency treatments and were imposed for 12 weeks between January and April, 2012. Each precipitation frequency treatment received the same total quantity of water over time (i.e., $726 \mathrm{~mL}$ deionized water per month, equivalent to $60 \mathrm{~mm}$ precipitation), so that the less frequent treatment was subjected to fewer, heavier precipitation events. The ambient frequency and quantity of water added were based on observations between 2007 and 2010 at a meteorological station of the Swedish Meteorological and Hydrological Institute (SMHI) in the Arjeplog area; see also [14]. The reduced precipitation frequency treatment simulates longer periods between rainfall events and heavier individual rainfall events that are expected to occur in the boreal forests of northern Sweden as a result of climate change [34-36]. Eighteen weeks after initial planting (i.e., April, 2012), all pots were destructively harvested, and the height of each seedling was measured. The shoots and roots of the seedlings were oven dried at $70{ }^{\circ} \mathrm{C}$ for 48 hours and weighed separately. Before the destructive harvest, moss depth was also measured. To assess moss growth during the experiment, the oven dry weight $\left(70{ }^{\circ} \mathrm{C}, 48\right.$ hours $)$ of the moss present in each pot at the end of the experiment was also measured and compared to the estimated biomass of the moss added to the pot at the start of the experiment.

\section{3. $N_{2}$-Fixation and Available Nutrients}

In each of the 12 blocks, we also set up an additional five pots, one for each of the four moss species, which had $80 \% \mathrm{MBC}$ and one pot that had no mosses $(0 \% \mathrm{MBC})$, resulting in a total of 60 pots. As described for the pots above, six of the 12 blocks received the ambient precipitation frequency and the other six the reduced precipitation frequency. These pots were not planted with seedlings and were instead used to study biological $\mathrm{N}_{2}$-fixation rates and soil nutrient fluxes to assess possible feedbacks of the moss species on the nutrient status of the pots. At the end of the experiment (i.e., after 18 weeks), we analyzed the cyanobacterial $\mathrm{N}_{2}$-fixation for the moss in each of these pots using the acetylene reduction method, as described in detail in previous studies focused on $\mathrm{N}_{2}$-fixation in mosses [1,14]. This involved random sampling of 30 shoots for P. schreberi or $P$. commune or 15 shoots for $H$. splendens or $S$. girgensohnii (which have larger shoots) from each pot. The samples from each pot were divided into three separate 22-mL glass vials and were fully hydrated with $3 \mathrm{~mL}$ deionized water, after which they were injected with a $10 \%$ headspace of acetylene. The samples were incubated in greenhouse conditions for 24 hours, after which the samples were analyzed for ethylene concentrations on a gas chromatograph using ethylene standards (Clarus 500 GC, PerkinElmer Inc. Waltham, Massachusetts). These concentrations were transformed to ethylene mass $\left(\mu \mathrm{mol} \cdot \mathrm{g}^{-1} \cdot \mathrm{day}^{-1}\right.$ ) using the universal gas law. We used the $3 \mathrm{~mol}$ acetylene $\mathrm{mol} \cdot \mathrm{N}^{-1}$ ratio as described in DeLuca et al. [43] to convert the measured ethylene ppm to a $\mathrm{N}_{2}$-fixation rate. After $\mathrm{N}_{2}$-fixation measurements were made, shoots were dried at $70{ }^{\circ} \mathrm{C}$ for 48 hours and weighed, so that $\mathrm{N}_{2}$-fixation rates could be reported on a per gram of moss basis.

We used the same pots as for determining $\mathrm{N}_{2}$-fixation rates (i.e., without seedlings) to assess soil nutrient availability. This was done by placing a resin capsule (PST1 capsule, Unibest Bozeman, 
Bozeman, MT, USA) containing approximately $1 \mathrm{~g}$ of mixed bed ionic resins in the humus layer of each pot at the beginning of the experiment [44]. These capsules were removed after 18 weeks and later extracted with three separate extractions of $10 \mathrm{~mL} 1 \mathrm{M} \mathrm{KCl}$, and run for $\mathrm{NH}_{4}{ }^{+}, \mathrm{NO}_{3}{ }^{-}$and $\mathrm{PO}_{4}{ }^{3-}$ on an Autoanalyzer 3 (SEAL Analytical).

\subsection{Statistical Analysis}

We analyzed most of the response variables (i.e., seedling height, shoot, root and total seedling biomass, shoot-to-root ratio and moss growth) using three-way ANOVAs, with moss species, MBC and precipitation frequency serving as fixed factors, and we included a random block factor. In order to meet the assumptions of normality and homogeneity of variances, seedling shoot, root and total biomass were square root transformed, whereas the shoot-to-root ratio was log transformed. The moss growth data was transformed with a square root +1 transformation. We compared the effects of moss species and precipitation frequency on $\mathrm{N}_{2}$-fixation rates and soil nutrients using two-way ANOVAs, including a random block factor. When significant differences were detected, we performed Tukey HSD post hoc tests. All statistical tests were performed in R v 2.12.1 from R Core Team (2012), except $t$-tests, which were performed in IBM SPSS Statistics 19, and the figures were compiled with GraphPad Prism 6.

\section{Results and Discussion}

\subsection{Effect of Moss Species}

We found that seedling height, shoot, root and total biomass, as well as the shoot-to-root ratio differed among the moss species present in the pots (Table 1). The presence of three of the four moss species (i.e., P. schreberi, H. splendens and S. girgensohnii) significantly increased the height growth of the seedlings (Figure 1a). Seedling biomass was most negatively affected by $H$. splendens and most positively by $S$. girgensohnii. However, the biomass of seedlings in pots containing any of the four moss species did not differ from that of seedlings grown in the moss-free control pots. Specifically, seedlings growing in $S$. girgensohnii achieved significantly more shoot biomass than they did in either $H$. splendens or P. commune (Figure 1b). The root biomass of the seedlings in the $S$. girgensohnii pots was also significantly larger than the root biomass of the seedlings grown in the other moss covered pots (Table 1, Figure 1c). The root biomass of the seedlings in pots with $P$. schreberi and $P$. commune was, in turn, significantly larger than those grown with $H$. splendens (Figure 1c). Total seedling biomass was highest when seedlings were grown in pots with P. schreberi and S. girgensohnii and lowest in pots covered with H. splendens and P. commune (Figure 1d). The shoot-to-root ratio of seedlings in $H$. splendens pots was almost statistically significantly larger than for seedlings in $S$. girgensohnii pots ( $p=0.062$, Figure 1e). 
Table 1. The effect of four moss species, moss biomass class and precipitation frequency and their interaction effects on Pinus sylvestris seedling and moss growth; values represent the results ( $F$-value) of a three-way ANOVA with replicates organized into blocks (serving as a random factor) and significant levels ( $p$-values) in parentheses; significant effects are shown in bold $(p<0.05)$.

Tree Seedling

\begin{tabular}{|c|c|c|c|c|c|c|}
\hline $\begin{array}{l}\text { Response } \\
\text { variable }\end{array}$ & Height & Shoot biomass & Root biomass & Total biomass & Shoot:root ratio & $\begin{array}{l}\text { Moss } \\
\text { growth }\end{array}$ \\
\hline Moss species (S) & $5.381(<0.001)$ & $4.975(<0.001)$ & $11.796(<0.001)$ & $8.631(<0.001)$ & $2.462(0.048)$ & $\begin{array}{l}104.114 \\
(<0.001)\end{array}$ \\
\hline $\begin{array}{l}\text { Moss biomass } \\
\text { class (MBC) }{ }^{1}\end{array}$ & $14.756(<0.001)$ & $3.881(0.010)$ & $14.682(<0.001)$ & $8.821(<0.001)$ & $6.886(<0.001)$ & $\begin{array}{c}55.788 \\
(<0.001)\end{array}$ \\
\hline $\begin{array}{l}\text { Precipitation } \\
\text { frequency }(\mathrm{W})\end{array}$ & $1.319(0.253)$ & $0.102(0.750)$ & $1.038(0.099)$ & $0.491(0.485)$ & $0.122(0.728)$ & $\begin{array}{r}23.620 \\
(<0.001) \\
\end{array}$ \\
\hline $\mathrm{S} \times \mathrm{MBC}$ & $1.807(0.071)$ & $1.934(0.051)$ & $2.229(0.023)$ & $2.237(0.022)$ & $0.477(0.888)$ & $\begin{array}{c}3.228 \\
(0.001)\end{array}$ \\
\hline $\mathrm{S} \times \mathrm{W}$ & $0.930(0.448)$ & $1.895(0.114)$ & $2.520(0.043)$ & $2.342(0.057)$ & $0.516(0.724)$ & $\begin{array}{c}2.523 \\
(0.060)\end{array}$ \\
\hline $\mathrm{MBC} \times \mathrm{W}$ & $0.940(0.423)$ & $2.131(0.099)$ & $1.016(0.387)$ & $1.658(0.178)$ & $0.810(0.490)$ & $\begin{array}{c}1.808 \\
(0.148)\end{array}$ \\
\hline $\mathrm{S} \times \mathrm{MBC} \times \mathrm{W}$ & $1.017(0.429)$ & $0.765(0.649)$ & $0.783(0.632)$ & $0.798(0.619)$ & $0.660(0.744)$ & $\begin{array}{c}0.541 \\
(0.843)\end{array}$ \\
\hline
\end{tabular}

Degrees of freedom (Df) for tree seedling and moss growth (within parenthesis) are as follows. S: $D f=4(3)$; $\mathrm{MBC}: D f=4(3) ; \mathrm{W}: D f=1(1) ; \mathrm{S} \times \mathrm{MBC}: D f=16(9) ; \mathrm{S} \times \mathrm{W}: D f=4(3) ; \mathrm{MBC} \times \mathrm{W}: D f=4(3) ; \mathrm{S} \times \mathrm{MBC} \times$ W: $D f=16(9)$; residuals: $D f=149(155) ;{ }^{1}$ The moss biomass class includes $0 \%$ (control), $8 \%, 20 \%, 40 \%$ and $80 \%$ of reference biomass values of each species.

Figure 1. Response of Pinus sylvestris seedlings grown in pots containing different moss species, averaged across precipitation regimes and all moss biomass classes (MBC), including a moss-free control; bars show the means + SE. Within each subpanel, different letters above bars indicate significant pairwise differences at $p<0.05$ (Tukey's HSD); ANOVA results are presented in Table 1.
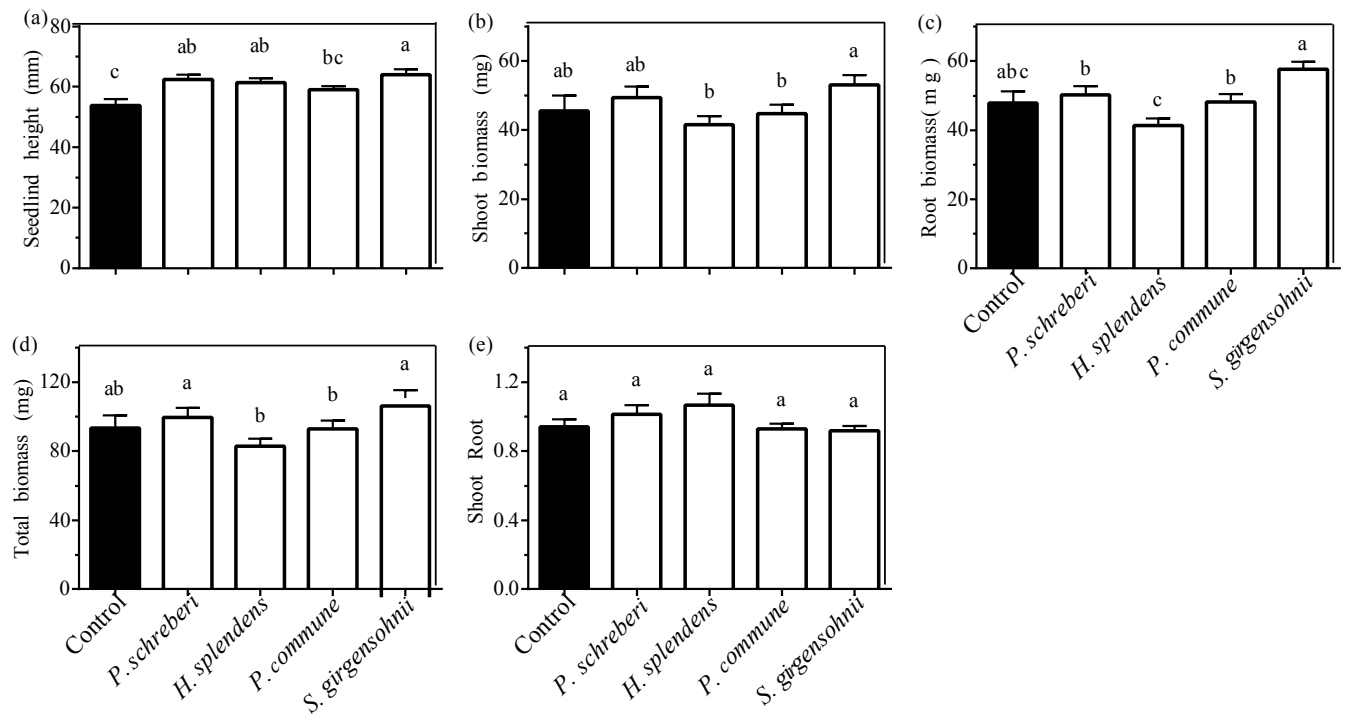


\subsection{Effect of Moss Biomass}

We found that moss biomass class (MBC) when averaged across all moss species had a significant impact on seedling growth (Table 1). As such, seedlings growing in the $40 \%$ and $80 \% \mathrm{MBC}$ pots were significantly taller than seedlings in the control and $8 \%$ MBC pots (Figure 2a). On average, seedlings were taller than the average moss depth in the $8 \%, 20 \%$ and $40 \% \mathrm{MBC}$, but shorter than moss depth in the $80 \%$ MBC (Figure S1a). Conversely, seedling biomass was negatively affected by the $80 \% \mathrm{MBC}$ compared to the other $\mathrm{MBC}$, but did not differ significantly from seedling biomass in the moss-free control pots. Specifically, the shoot biomass of the seedlings was significantly lower in the $80 \% \mathrm{MBC}$ compared to the $20 \% \mathrm{MBC}$ pots (Figure $2 \mathrm{~b}$ ). The root and total biomass of the seedlings grown at $80 \%$ MBC were significantly lower compared to the root and total biomass of the seedlings in the $8 \%, 20 \%$ and $40 \%$ MBC pots, but not compared to the control (Figure 2c,d). The shoot-to-root ratio was significantly higher in the $80 \% \mathrm{MBC}$ pots relative to all other MBC treatments, but not relative to the control (Figure 2e).

Figure 2. Response of Pinus sylvestris seedlings grown in pots containing different moss species of different moss biomass class (MBC), including a moss-free control, averaged across precipitation regimes and all moss species; bars show means $+\mathrm{SE}$; within each subpanel, different letters above bars indicate significant pairwise differences at $p<0.05$ (Tukey's HSD); ANOVA results are presented in Table 1.
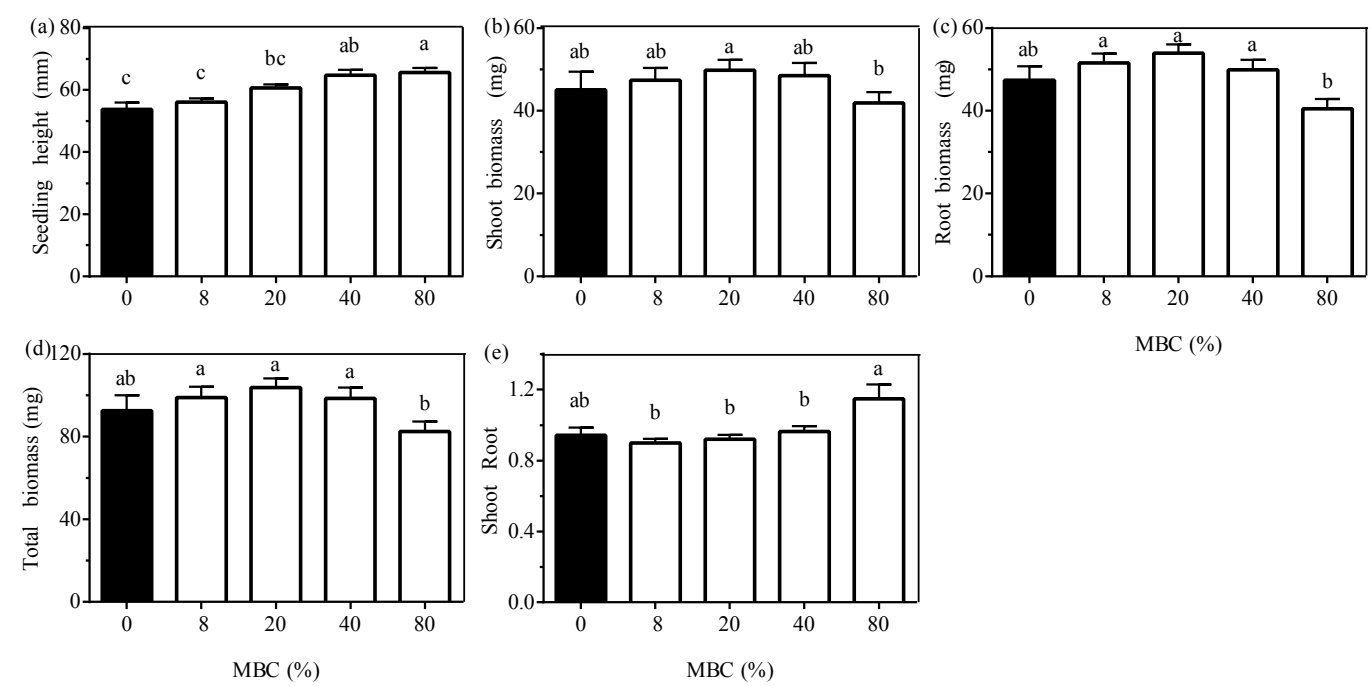

\subsection{Effects of the Interaction between Moss Species and Moss Biomass}

A significant effect of the interaction between moss species and MBC was found for seedling root and total biomass (Table 1). These interactions showed that the effect of increasing moss biomass (i.e., $\mathrm{MBC}$ ) on seedling growth was not equal for all moss species. For both root and total seedling biomass, the significant effect of the interaction between moss species and $\mathrm{MBC}$ was due to a strong negative effect of $H$. splendens in the $80 \%$ MBC pots (Figure 3). There was also a significant effect of MBC on both variables in $S$. girgensohnii pots according to ANOVA (Table 2), but the post hoc comparison (Tukey's HSD) did not show a difference between moss biomass classes for this species (Figure 3). There was no effect of MBC on root or total seedling biomass in the $P$. schreberi and $P$. commune pots 
(Table 2, Figure 3). Measurements of moss depth in the $80 \% \mathrm{MBC}$ pots were significantly higher for $H$. splendens than for P. schreberi and S. girgensohnii (Figure S1b).

Figure 3. Response of Pinus sylvestris (a) seedling root biomass and (b) total seedling biomass across moss species and all moss biomass classes (MBC); bars show means $+\mathrm{SE}$; significant differences are shown by different letters at $p<0.05$ (Tukey's HSD); ANOVA results are presented in Tables 1 and 2 .
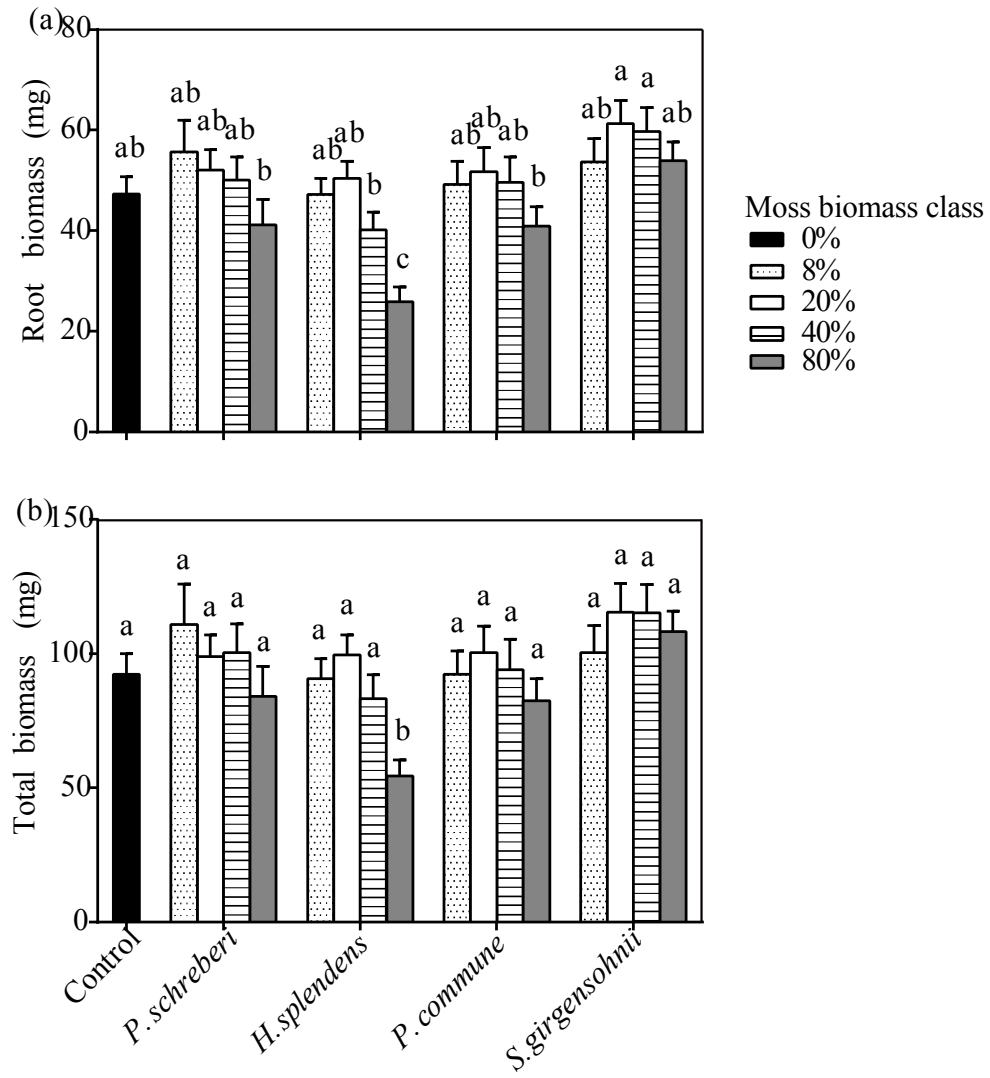

Table 2. The effect of moss biomass class (MBC) and precipitation frequency (W) on Pinus sylvestris seedling and moss growth for each of four moss species; there were no significant interaction effects between $\mathrm{MBC}$ and precipitation frequency for any of the species and response variables (results not presented); the values show the results $(F$-value) and significant levels ( $p$-values) in parentheses of a two-way ANOVA with replicates organized into blocks (serving as a random factor); significant effects are shown in bold $(p<0.05)$.

\begin{tabular}{|c|c|c|c|c|c|c|c|}
\hline \multirow[b]{2}{*}{ Moss species } & & \multicolumn{5}{|c|}{ Tree Seedling } & \multirow[b]{2}{*}{$\begin{array}{c}\text { Moss } \\
\text { growth }\end{array}$} \\
\hline & & Height & $\begin{array}{c}\text { Shoot } \\
\text { biomass }\end{array}$ & $\begin{array}{c}\text { Root } \\
\text { biomass }\end{array}$ & $\begin{array}{c}\text { Total } \\
\text { biomass }\end{array}$ & $\begin{array}{c}\text { Shoot:root } \\
\text { ratio }\end{array}$ & \\
\hline \multirow[t]{2}{*}{ P. schreberi } & $\mathrm{MBC}^{1}$ & $5.595(0.001)$ & $\begin{array}{c}1.005 \\
(0.417)\end{array}$ & $\begin{array}{c}2.439 \\
(0.063)\end{array}$ & $\begin{array}{c}1.646 \\
(0.182)\end{array}$ & $\begin{array}{c}1.518 \\
(0.215)\end{array}$ & $\begin{array}{c}20.621 \\
(<0.001)\end{array}$ \\
\hline & $\mathrm{W}$ & $0.459(0.502)$ & $\begin{array}{c}0.072 \\
(0.789)\end{array}$ & $\begin{array}{c}0.081 \\
(0.777)\end{array}$ & $\begin{array}{c}0.099 \\
(0.754)\end{array}$ & $\begin{array}{c}0.089 \\
(0.767)\end{array}$ & $\begin{array}{c}6.081 \\
(0.020)\end{array}$ \\
\hline
\end{tabular}


Table 2. Cont.

\begin{tabular}{|c|c|c|c|c|c|c|c|}
\hline \multirow[b]{2}{*}{ Moss species } & \multicolumn{7}{|c|}{ Tree Seedling } \\
\hline & & Height & $\begin{array}{c}\text { Shoot } \\
\text { biomass }\end{array}$ & $\begin{array}{c}\text { Root } \\
\text { biomass }\end{array}$ & $\begin{array}{c}\text { Total } \\
\text { biomass }\end{array}$ & $\begin{array}{c}\text { Shoot:root } \\
\text { ratio }\end{array}$ & $\begin{array}{l}\text { Moss } \\
\text { growth }\end{array}$ \\
\hline \multirow[t]{2}{*}{ H. splendens } & $\mathrm{MBC}^{1}$ & $7.587(<0.001)$ & $\begin{array}{c}6.729 \\
(<0.001)\end{array}$ & $\begin{array}{c}14.863 \\
(<0.001)\end{array}$ & $\begin{array}{c}11.290 \\
(<0.001)\end{array}$ & $\begin{array}{c}2.392 \\
(0.067)\end{array}$ & $\begin{array}{c}12.073 \\
(<0.001)\end{array}$ \\
\hline & W & $1.071(0.307)$ & $\begin{array}{c}0.188 \\
(0.667)\end{array}$ & $\begin{array}{c}0.082 \\
(0.776)\end{array}$ & $\begin{array}{c}0.166 \\
(0.686)\end{array}$ & $\begin{array}{c}0.404 \\
(0.528)\end{array}$ & $\begin{array}{l}14.329 \\
(0.001)\end{array}$ \\
\hline \multirow[t]{2}{*}{ P. commune } & $\mathrm{MBC}^{1}$ & $2.977(0.032)$ & $\begin{array}{c}0.605 \\
(0.662)\end{array}$ & $\begin{array}{c}2.147 \\
(0.094)\end{array}$ & $\begin{array}{c}1.149 \\
(0.349)\end{array}$ & $\begin{array}{c}1.439 \\
(0.240)\end{array}$ & $\begin{array}{c}3.016 \\
(0.045)\end{array}$ \\
\hline & $\mathrm{W}$ & $0.877(0.355)$ & $\begin{array}{c}4.913 \\
(0.033)\end{array}$ & $\begin{array}{c}7.783 \\
(0.008)\end{array}$ & $\begin{array}{c}6.712 \\
(0.014)\end{array}$ & $\begin{array}{c}0.120 \\
(0.731)\end{array}$ & $\begin{array}{c}0.202 \\
(0.656)\end{array}$ \\
\hline \multirow[t]{2}{*}{ S. girgensohnii } & $\mathrm{MBC}^{1}$ & $18.315(<0.001)$ & $\begin{array}{c}2.129 \\
(0.095)\end{array}$ & $\begin{array}{c}3.085 \\
(0.026)\end{array}$ & $\begin{array}{c}2.754 \\
(0.041)\end{array}$ & $\begin{array}{c}2.252 \\
(0.080)\end{array}$ & $\begin{array}{c}35.191 \\
(<0.001)\end{array}$ \\
\hline & W & $1.479(0.231)$ & $\begin{array}{c}2.711 \\
(0.108)\end{array}$ & $\begin{array}{c}3.164 \\
(0.083)\end{array}$ & $\begin{array}{c}3.503 \\
(0.069)\end{array}$ & $\begin{array}{c}0.006 \\
(0.938)\end{array}$ & $\begin{array}{l}10.050 \\
(0.003)\end{array}$ \\
\hline
\end{tabular}

Degrees of freedom (Df) for tree seedling and moss growth (within parenthesis) are as follows; MBC: $D f=4(3)$; W: $D f=1(1)$; residuals: $D f=45(35) ;{ }^{1}$ Moss biomass class includes $0 \%$ (control), $8 \%, 20 \%, 40 \%$ and $80 \%$ of reference biomass values of each species.

\subsection{Precipitation Effect}

We did not find any main effect of the precipitation frequency on seedling biomass (Table 1); however, there was a significant and marginally non-significant interactive effect at $p=0.05$ of precipitation treatment and species on seedling root biomass and total biomass, respectively (Table 1). These interactive effects were mainly driven by significantly higher shoot, root and total seedling biomass in the ambient precipitation frequency compared to the reduced precipitation frequency for P. commune, but not for the other species (Table 2). Specifically, when averaged across all MBC treatments for $P$. commune, the shoot, root and total seedling biomass (mean $\pm \mathrm{SE}$ ) was $49.1 \mathrm{mg} \pm 3.9$, $51.9 \mathrm{mg} \pm 3.0$ and $101.0 \mathrm{mg} \pm 6.8$, respectively, under the ambient precipitation frequency and $40.8 \mathrm{mg} \pm 2.1,44.3 \mathrm{mg} \pm 2.8$ and $85.1 \mathrm{mg} \pm 4.0$ at the reduced precipitation frequency. When testing specifically for the precipitation effect on seedling growth in the moss-free control pots, we did not find significant differences in seedling performance between precipitation frequencies ( $t$-test values ( $p$-value) were: seedling shoot biomass: 0.553 (0.592); root biomass: -0.459 (0.656); total biomass: 0.110 (0.915); shoot:root ratio: 1.729 (0.114); and seedling height: 0.293 (0.776)).

\subsection{Moss Growth}

Over the course of the experiment, the growth of the mosses differed across species with $S$. girgensohnii showing the largest moss biomass growth and $P$. commune the lowest (Table 1, Figure 4a). The largest moss biomass growth per pot was achieved in the pots with the highest MBC (Tables 1 and 2, Figure 4a). This pattern was consistent for all moss species, even though the magnitude differed between species (i.e., no significant differences within the P. commune pots), which was reflected in the interactive effect of moss species and MBC (Table 1, Figure 4a). Across all 
pots, the moss biomass increased by $43 \%$ during the 18 weeks of the experiment. However, the relative moss biomass growth was the largest in the pots with the lowest MBC present for which the moss biomass on average increased by $78 \%$ (data not shown). During the experiment, the moss biomass in the $80 \% \mathrm{MBC}$ treatment for P. schreberi and H. splendens increased by $1.4 \pm 0.2$ and $1.6 \pm 0.3 \mathrm{~g}$ dry weight $\operatorname{pot}^{-1}$ (mean $\pm \mathrm{SE}$ ), respectively. This means that over this time, the biomass for these two species became similar to the $100 \%$ reference biomass value, as a moss growth of $1.5 \mathrm{~g}$ dry weight pot $^{-1}$ would be needed for reference biomass values to be achieved (Figure 4a). Meanwhile, for S. girgensohnii, growth in the $80 \% \mathrm{MBC}$ treatment was $2.8 \pm 0.3 \mathrm{~g}$ dry weight $\operatorname{pot}^{-1}$, meaning that the final biomass greatly exceeded the $100 \%$ reference biomass value. There was a significant overall effect of precipitation frequency on moss growth (Table 1), with mosses growing better under ambient than reduced frequency. When species were considered separately, this effect was statistically significant for all moss species, except $P$. commune (Table 2, Figure 4b). Moss depth showed an overall negative response to reduced precipitation frequency (ANOVA $F_{1.158}=4.962, p=0.027$ ), but no significant effects on precipitation frequency within each species were found (Tukey's HSD, data not shown).

Figure 4. Moss biomass growth (dry weight) per pot of each of the four moss species during the course of the experiment: (a) averaged across precipitation regimes and expressed for each initial moss biomass class (MBC); and (b) averaged across all moss biomass classes (MBC) and expressed in relation to precipitation frequency (ambient and reduced); all moss species had the same starting dry weight for each biomass class; different capital letters show significant differences at $p<0.05$ (Tukey's HSD) among moss species (a), and different lower case letters show significant differences at $p<0.05$ (Tukey's HSD) among moss biomass classes (a) and precipitation frequency treatments (b); bars show means + SE. ANOVA results are presented in Tables 1 and 2.
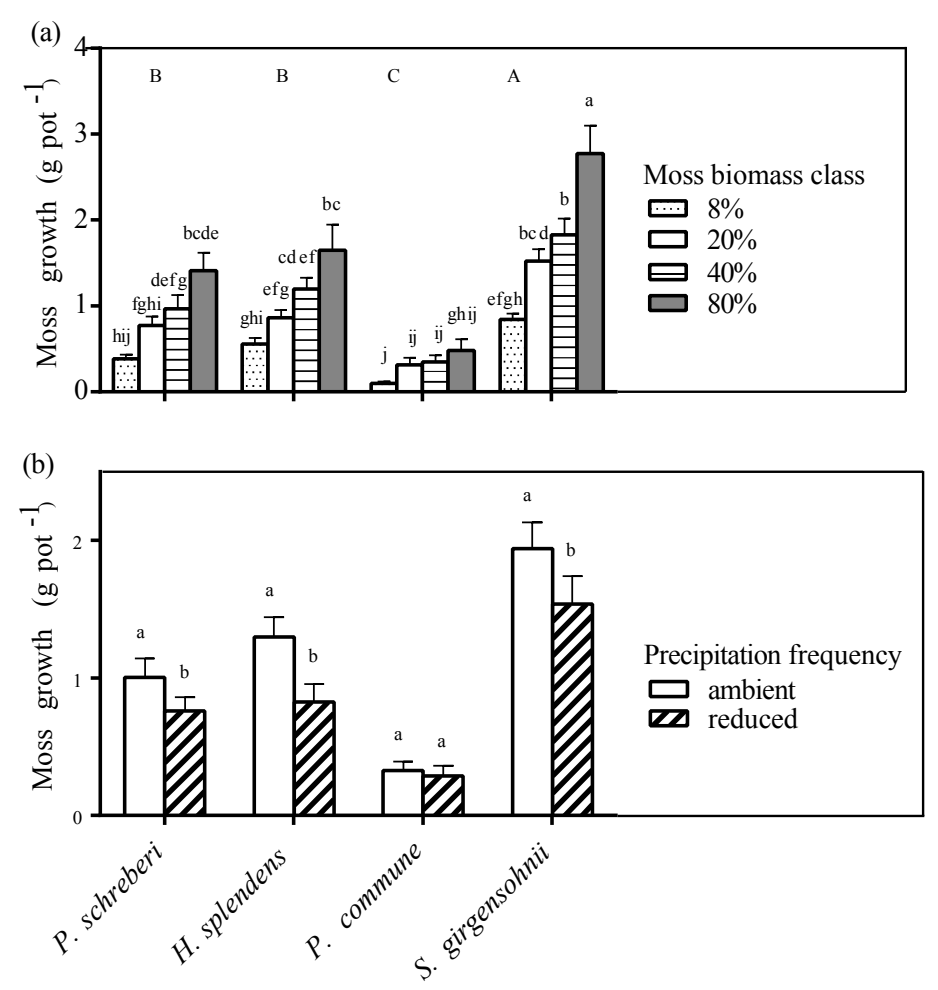


\subsection{Effect of Moss Species on $\mathrm{N}_{2}$-Fixation and Nutrient Availability}

The amount of $\mathrm{N}_{2}$ fixed by cyanobacteria that live in symbiosis with mosses differed between moss species (Table 3); the highest $\mathrm{N}_{2}$-fixation rates occurred in the Pleurozium schreberi and $H$. splendens pots, while in the $P$. commune pots, no $\mathrm{N}_{2}$-fixation took place (Table 3, Figure 5a). Additionally, the moss species differed significantly in their effects on soil $\mathrm{NO}_{3}{ }^{-}-\mathrm{N}$ and $\mathrm{PO}_{4}{ }^{3-}-\mathrm{P}$, but not $\mathrm{NH}_{4}{ }^{+}-\mathrm{N}$ measured in the resin capsules (Table 3). The presence of three of the moss species (i.e., P. schreberi, $P$. commune and $S$. girgensohnii) had a positive effect on the amount of resin sorbed $\mathrm{NO}_{3}{ }^{-}-\mathrm{N}$ relative to the moss free control (Figure 5b). Further, significantly lower amounts of resin sorbed $\mathrm{PO}_{4}{ }^{3-}-\mathrm{P}$ were found in pots with $P$. commune and $S$. girgensohnii present compared to pots with $P$. schreberi (Figure 5c), but not compared to the control. There were no effects of precipitation frequency, or interactive effects of frequency and species, on $\mathrm{N}_{2}$ fixation or on sorption of any of the nutrients by resin capsules (Table 3 ).

Table 3. The effect of moss species, precipitation frequency and the moss species $\times$ precipitation frequency interaction on $\mathrm{N}_{2}$ fixation rates and sorbed soil nutrients $\left(\mathrm{NH}_{4}{ }^{+}-\mathrm{N}, \mathrm{NO}_{3}{ }^{-}-\mathrm{N}\right.$ and $\left.\mathrm{PO}_{4}{ }^{3-}-\mathrm{P}\right)$ by resin capsules; the values show the results ( $F$-value) and significant levels ( $p$-values) in parentheses of a two-way ANOVA with the block as a random factor; significant effects are shown in bold $(p<0.05)$.

\begin{tabular}{lcccc}
\hline Response Variable & $\mathbf{N}_{\mathbf{2}}$ Fixation & $\mathbf{N H}_{\mathbf{4}}{ }^{-}-\mathbf{N}$ & $\mathbf{N O}_{3}{ }^{-}-\mathbf{N}$ & $\mathbf{P O}_{4}{ }^{{ }^{-}-}-\mathbf{P}$ \\
\hline Moss species (S) & $\mathbf{1 6 . 7 8 0}(<\mathbf{0 . 0 0 1})$ & $1.097(0.371)$ & $\mathbf{6 . 3 4 0}(<\mathbf{0 . 0 0 1})$ & $\mathbf{5 . 3 6 8}(\mathbf{0 . 0 0 1})$ \\
Precipitation frequency (W) & $0.772(0.387)$ & $0.368(0.548)$ & $0.068(0.795)$ & $0.138(0.711)$ \\
$\mathrm{S} \times \mathrm{W}$ & $1.903(0.151)$ & $0.312(0.868)$ & $0.348(0.844)$ & $0.213(0.930)$ \\
\hline
\end{tabular}

$\mathrm{N}_{2}$ fixation: $\mathrm{S}: D f=3 ; \mathrm{W}: D f=1 ; \mathrm{S} \times \mathrm{W}: D f=3$; residuals $D f=35 ; \mathrm{NH}_{4}{ }^{+}-\mathrm{N}, \mathrm{NO}_{3}{ }^{-}-\mathrm{N}, \mathrm{PO}_{4}{ }^{3-}-\mathrm{P}: \mathrm{S}: D f=4$; $\mathrm{W}: D f=1 ; \mathrm{S} \times \mathrm{W}: D f=4$; residuals $D f=45$.

Figure 5. Biogeochemical properties associated with the four moss species at the highest moss biomass class and a moss-free control: (a) biological $\mathrm{N}_{2}$-fixation; (b) resin sorbed soil $\mathrm{NO}_{3}{ }^{-}-\mathrm{N}$; and (c) resin sorbed soil $\mathrm{PO}_{4}{ }^{3-}-\mathrm{P}$. Bars show means $+\mathrm{SE}$; means within each panel topped with different letters show significant differences between the moss species (Tukey's HSD, $p<0.05$ ); ANOVA results are presented in Table 3.
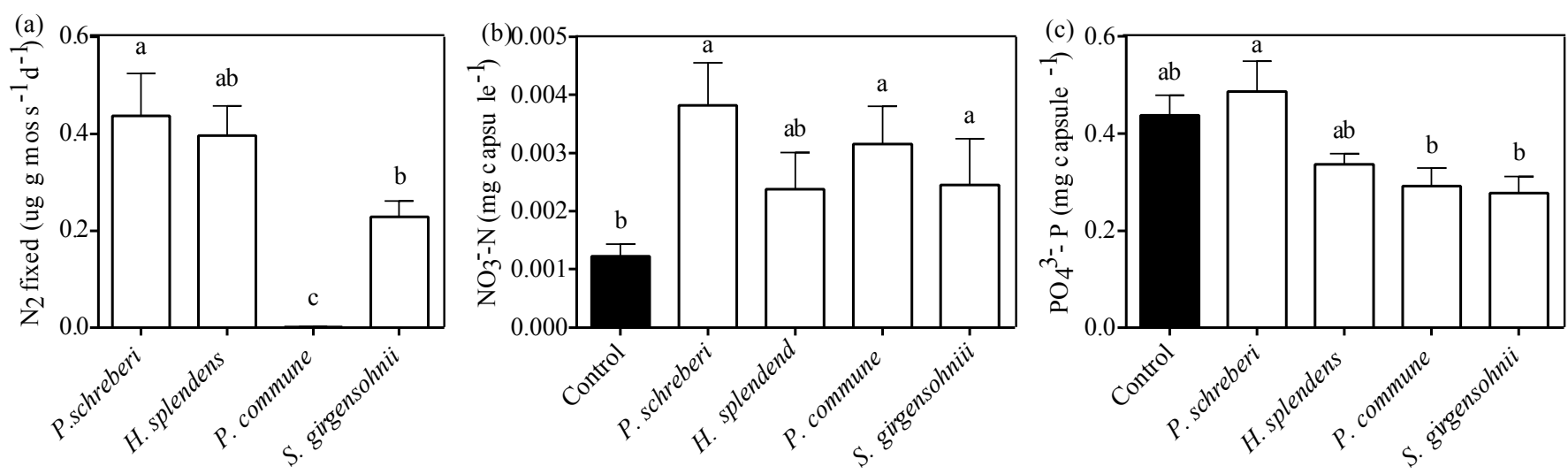


\subsection{Discussion}

Even though research on how mosses influence vascular plants has attracted increasing attention during the last decade, much is still unknown of the driving processes behind these effects [2]. The aim of this study was to improve our understanding of the influence that mosses may have on the growth of $P$. sylvestris seedlings and to determine how this influence varies among different moss species, levels of moss biomass and precipitation frequencies. We found that $P$. sylvestris seedling growth could be either reduced or promoted depending on the moss species and the biomass of the moss layer in which the seedlings grew. Even though moss growth was decreased by reduced precipitation frequency for three of the four moss species, our study provided little evidence that this, in turn, modifies seedling growth.

In agreement with our first hypothesis, we found that moss species differed in their effects on $P$. sylvestris seedling growth. Three of the four moss species caused seedlings to grow significantly taller compared to when no mosses were present. These results are consistent with a previous study on other species, where Picea glauca seedlings grew taller with Polytrichum spp. compared to when the moss layer was absent [30]. These findings suggest that the seedlings experience a limitation in light availability induced by the moss layer, whereby seedlings increase their height growth to avoid light competition $[45,46]$. When total seedling biomass was considered, we found the lowest biomass when seedlings were grown with $H$. splendens and $P$. commune and highest when grown with $S$. girgensohnii and P. schreberi, even when moss biomass was kept constant across species. This means that the differences across moss species in their effects were due to differences in moss species attributes that are independent of moss biomass. The morphology of both $H$. splendens and $P$. commune differs from that of the other two species in that they have a stronger support system and taller growth form [5,39]. This taller growth form would have caused lower light availability, resulting in lower biomass production of the seedlings. The negative effect of $H$. splendens and $P$. commune relative to the other two species could not be explained in terms of the modification of soil nutrient availability for the seedlings, because available levels of soil nutrients were never impaired by the presence of mosses. However, unlike for the other three species, atmospheric $\mathrm{N}_{2}$-fixation was absent in the $P$. commune pots, and this species also has the lowest water retention capacity [21,22]; both of these factors could have contributed to its negative effect on seedling growth. In contrast, the positive effect of $S$. girgensohnii and $P$. schreberi on seedling biomass relative to the other two species may have been due to a combination of factors. For S. girgensohnii, its high water retention capacity provided by its hyaline cell structure may have increased the accessibility of moisture or nutrients to seedlings [21,47]. Likewise, both of these species enhanced soil $\mathrm{NO}_{3}{ }^{-} \mathrm{N}$ availability and supported $\mathrm{N}_{2}$-fixation and were less likely to cause light limitation of the seedlings because of their shorter stature. The contrasting effect of the moss species used in this study is partly in agreement with previous research, which showed that Sphagnum spp. enhanced the performance of $P$. abies seedlings, while H. splendens impaired them [5]. However, most studies have found that P. schreberi affected seedling emergence negatively [4,20], which contradicts our findings.

Contrary to the predictions of our second hypothesis, we found no evidence of enhanced seedling performance in the intermediate moss biomass classes; instead, we found that seedling biomass was reduced by the highest biomass level, but did not differ significantly among the other levels. Our 
results also showed that seedling height and shoot-to-root ratios were highest in the highest moss biomass class. This suggests that moss cushions with high field biomass cause seedlings to grow taller slender shoots that contain less biomass and allocate more $\mathrm{C}$ aboveground than belowground. Our finding is in agreement with previous work showing that the presence of mosses can increase seedling aboveground biomass allocation and height and decrease stem diameter [29,30]; our results extend those findings by showing that these types of changes occur primarily when moss biomass is at or near the maximum biomass likely to be found in natural or field conditions. The fact that seedlings allocate more resources to shoots relative to roots is most likely driven by shading by the mosses and is aimed at enabling seedlings to avoid light competition [45]. This effect was greatest in the highest moss biomass class, because both moss depth and shoot density were highest in this treatment and because this treatment showed the greatest increase in moss biomass during the experiment, which should maintain these competitive effects through time.

In addition to the decline in seedling growth in the highest MBC across all species, the data also showed several species-specific responses to the MBC treatments, as revealed by an effect of the interaction between moss species and MBC on root and total biomass. This interaction effect was largely driven by the strong negative response of seedling root and total biomass to the highest moss biomass $(80 \% \mathrm{MBC})$ treatment for $H$. splendens, but not for the other three moss species. The particularly negative effect of $H$. splendens in the highest MBC was explained by the greater depth of the moss layer for this species and the size of its mature shoot segments, which have been shown to increase in size when density is high [48]. The horizontal growth form of $H$. splendens leaves on annual segments likely further contributes to effectiveness in intercepting light [21,39]. Even though the moss layer should cause a decrease in light availability, seedlings are often able to use resources from their seeds for initial growth [49,50], which allows them to grow above the moss layer to maximize photosynthesis. Our study showed that the critical moss depth at which mosses competitively suppress $P$. sylvestris seedlings is approximately $70 \mathrm{~mm}$. However, it is important to recognize that under natural conditions, mosses increase their aboveground biomass until late summer or early autumn, while seedling shoot growth stops earlier in the summer [5,51], meaning that mosses are able to overgrow the seedlings when they are inactive. This is also supported by findings that the mortality of seedlings is mainly due to smothering [5,52]. Consequently, our results suggest that moss depth rather than moss biomass is the most important attribute in explaining seedling performance. This is supported by several studies where thinner moss layers have been shown to be associated with improved seedling establishment relative to thicker moss layers $[53,54]$.

We found limited support for our third hypothesis that seedlings would be less sensitive to reductions in precipitation frequency when grown in pots with mosses compared to without. Further, we found no evidence that reduced precipitation frequency impacted seedlings more when less moss biomass was present. We expected that higher moss biomass would provide more favorable moisture conditions to the seedlings, as suggested by previous studies $[48,55]$; however, our data showed that seedling growth was not limited by the moisture (i.e., precipitation frequency) treatments in our experiment. Although seedlings were unaffected by precipitation frequency, moss growth of every species, except $P$. commune, was negatively impacted by the reduced precipitation frequency, showing that this treatment was effective at reducing moisture availability in the moss layer. This reduced growth was expected, given that most mosses are poikilohydric and that their water content should 
therefore be strongly influenced by the surrounding environment [24,39]. The lack of response of $P$. commune to precipitation frequency could be because it was less water limited than the other species. Of the four species, this is the species with the lowest water retention capacity [21,22], but it is also the only one with an underground rhizome through which it can transport water and nutrients up from the soil into its water conducting tissue inside the stem [27,39]. These specific characteristics could be the reason that we found a significant effect of the precipitation treatment when seedlings were grown with $P$. commune. It is possible that the seedlings had to compete directly with $P$. commune, but not with the other three species, for soil moisture. Even though the experiment was conducted in a greenhouse environment, the moss biomass increased in all MBC categories, indicating that the mosses remained healthy during the experiment and can therefore be considered as comparable to moss cushions in natural forest conditions. Although $P$. commune showed visual signs of desiccation stress, which is probably due to the impact of transplantation, it also increased in biomass and grew new shoots. In natural conditions, the negative effect of transplantations would be absent and might lead to $P$. commune having a stronger impact on seedling growth than our data indicated. Our data suggests that seedlings in stands with abundant $P$. commune cover may be particularly impacted by extended periods without rainfall, which is predicted to become more common in the boreal region as a result of global climate change [34].

Our results showed that moss species had varying effects on seedling growth relative to the moss-free control, in contrast to many studies that have primarily reported negative impacts of mosses $[4,5,32]$. However, there are also studies which have shown that some site conditions which exert negative effects on seed germination are also those that are the most suitable for seedling establishment [20,56]. Since our study used seedlings from already germinated seeds, it remains unclear whether the factors we focused on would have the same impact on the germination process, and this would require further examination. Previous studies have also shown other mechanism by which mosses and vascular plants interact. For example, under natural conditions in boreal and arctic regions, the moss layer influences soil temperature fluctuations [13,54], which can, in turn, impact soil biota and nutrient mineralization rates [26]. These effects have potential consequences for seedling establishment [13], as well as for the abundance of other vascular plants that may serve as competitors for establishing tree seedlings [32,53]. As such, there are likely to be multiple ways through which mosses and their interaction with the environment may impact on establishing tree seedlings and potentially affect the success rates of forest regeneration, in addition to the pathways addressed in our study.

\section{Conclusions}

The effect of mosses on $P$. sylvestris seedlings is dependent on which moss species and in what moss biomass they grow. These effects may be negative as a consequence of competition by mosses for light and positive as a consequence of several factors, including the ability of mosses to supply seedlings with resources and to modify their abiotic environment. Our data showed that seedlings responded to variation in moss biomass (and particularly moss depth), through increased height and allocation of resources aboveground relative to belowground. The competitive effects of mosses were greatest when mosses were at their maximum biomass, but this effect varied among moss species and 
was strongest for seedlings surrounded by H. splendens, because this species had a greater depth of the moss layer than the other species at this biomass. Our findings are relevant for understanding forest regeneration in boreal forests, since it is known that changes in both moss species composition and biomass occur during forest succession after both natural and anthropogenic disturbances [18,57]. The values we used in the $80 \%$ moss biomass classes $\left(500 \mathrm{~g} / \mathrm{m}^{2}\right)$ were comparable to moss biomass values of $P$. schreberi and H. splendens measured in $140 \mathrm{y}$-old uncut forest stands in Eastern Finland, while moss biomass during the first seven years after clear-cutting was about $50 \%$ of this value [18]. It is also known that mosses can be strongly affected by global change factors, such as atmospheric $\mathrm{N}$ deposition [44,58], climatic warming and changes in precipitation regimes [2,26]. As we have shown in this study, changes in precipitation can drastically affect moss growth and the amount of moss biomass present in the forest. Consequently, our findings regarding the response of seedlings to a variety of moss conditions have important implications for understanding future forest regeneration in boreal forests under a changing global environment.

\section{Supplementary Information}

Prior to experimental set-up, we first established reference values to achieve a realistic weight estimate to represent the biomass per unit area of natural dense monoculture moss cushions. From these reference values, we determined the classes of the initial moss biomass to be used in the pots. These reference samples were also used to establish the relationship between the fresh weight (saturated conditions) and dry weight of individual moss cushions (Table S1). The mosses were therefore cleaned from litter and any other moss species present, saturated by submerging in water for at least 30 minutes, spun with 20 pulses for approximately one minute to release external water according to Fenton et al. [59], weighed (to obtain the fresh weight) and then oven dried (70 ${ }^{\circ} \mathrm{C}$, 48 hours) and weighed again to get the oven-dry weight.

Table S1. Natural standing biomass (mean \pm SE) of monospecific moss cushions collected from the field and the dry: fresh weight ratio of these cushions for each of the four moss species used in the experiment; the natural standing biomass was used to determine the highest moss biomass class to be used for each species when the experiment was set up, which was set at $500 \mathrm{~g} \cdot \mathrm{m}^{-2}$ equal, which is approximately $80 \%$ of the natural standing biomass averaged across all species (see the Methods section); the dry:fresh weight ratios were used during the experimental set-up to determine the amount of moss wet weight that corresponded to a given dry weight.

\begin{tabular}{lcc}
\hline Species & $\begin{array}{c}\text { Natural Monoculture Moss Cushion Biomass } \\
\left(\mathbf{D W} \mathbf{~ g} \cdot \mathbf{~ m}^{-\mathbf{2}} \text { ) }\right.\end{array}$ & $\begin{array}{c}\text { Cushion Dry/ } \\
\text { Fresh Weight Ratio }\end{array}$ \\
\hline Pleurozium schreberi $^{1}$ & $651 \pm 172$ & $0.078 \pm 0.004$ \\
Hylocomium splendens $^{2}$ & $569 \pm 144$ & $0.098 \pm 0.010$ \\
Polytrichum commune $^{2}$ & $661 \pm 146$ & $0.176 \pm 0.013$ \\
Sphagnum girgensohnii $^{1}$ & $592 \pm 44$ & $0.055 \pm 0.001$ \\
Mean & 618 & \\
$80 \%$ of mean weight & 495 & \\
\hline & ${ }^{1} n=4 ;{ }^{2} n=3$.
\end{tabular}


Figure S1. (a) Pinus sylvestris seedling height (white bars) and moss depth (black bars) at the end of the experiment for each moss biomass class (MBC) across all moss species and (b) for each moss species at the $80 \% \mathrm{MBC}$; for both panels, different lower case letters indicate significant differences in seedling height at $p<0.05$ and different capital letters indicate significant differences in moss depth at $p<0.05$ according to Tukey's HSD test; ANOVA results for seedling height across MBC are given in Table 1; and for moss species at $80 \%$ MBC $F_{3.39}=0.68(p=0.60)$; for moss depth, across $\mathrm{MBC} F_{3.155}=285.86$ $(p<0.001)$; and for moss species at $80 \% \operatorname{MBC} F_{3.39}=11.77(p<0.001)$; bars show means $+\mathrm{SE}$; the vertical axis scale refers to both seedling height and moss depth.
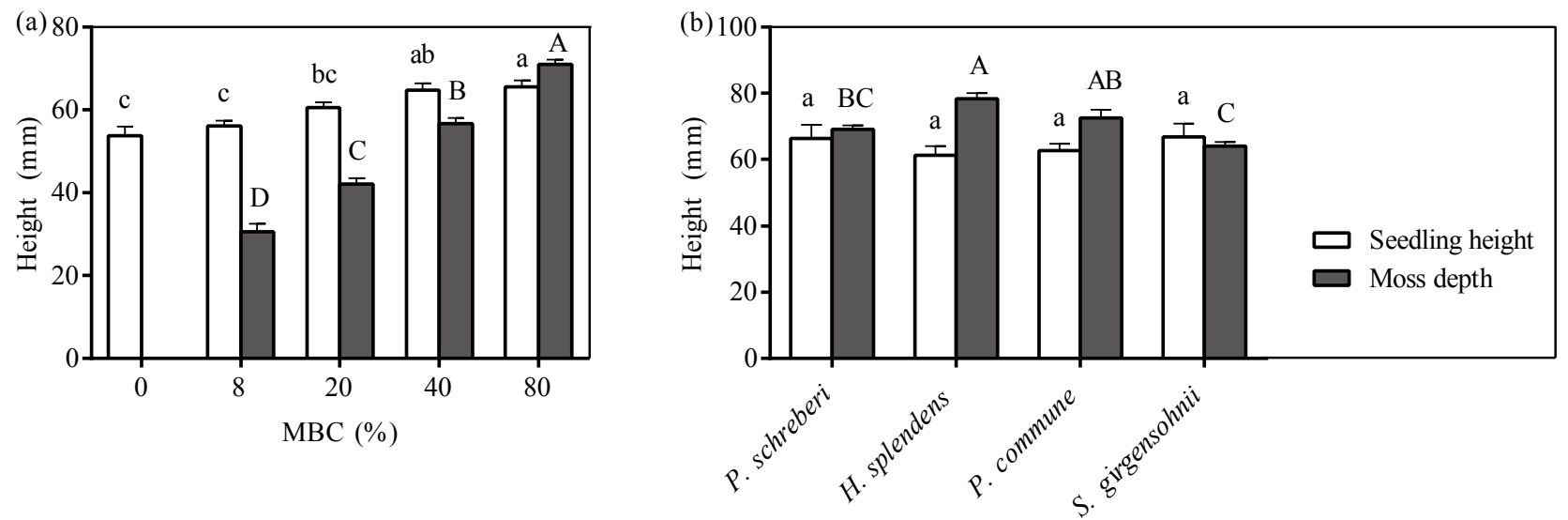

\section{Acknowledgments}

The research was funded by a TC4F (Trees and Crops for the Future) grant. We would like to thank Kelley Gundale and Margareta Söderström for laboratory assistance; and Agnes Väppling, Maja Sandström and David Rehmberg for assisting in the preparations and harvesting of the experiment.

\section{Author Contributions}

All authors contributed to the experimental design, data interpretation and writing of this article. Babs Stuiver executed the experiment and also performed the statistical analysis.

\section{Conflicts of Interest}

The authors declare no conflict of interest.

\section{References and Notes}

1. Gundale, M.J.; Gustafsson, H.; Nilsson, M.-C. The sensitivity of nitrogen fixation by a feathermoss-cyanobacteria association to litter and moisture variability in young and old boreal forests. Can. J. For. Res. 2009, 39, 2542-2549.

2. Turetsky, M.R.; Bond-Lamberty, B.; Euskirchen, E.; Talbot, J.; Frolking, S.; McGuire, A.D.; Tuittila, E.S. The resilience and functional role of moss in boreal and arctic ecosystems. New Phytol. 2012, 196, 49-67. 
3. Hyppönen, M.; Hallikainen, V.; Niemelä, J.; Rautio, P. The contradictory role of understory vegetation on the success of Scots pine regeneration. Silva Fenn. 2013, 47, doi:org/10.14214/sf.903.

4. Steijlen, I.; Nilsson, M.-C.; Zackrisson, O. Seed regeneration of Scots pine in boreal forest stands dominated by lichen and feather moss. Can. J. For. Res. 1995, 25, 713-723.

5. Hörnberg, G.; Ohlson, M.; Zackrisson, O. Influence of bryophytes and microrelief conditions on Picea abies seed regeneration patterns in boreal old-growth swamp forests. Can. J. For. Res. 1997, 27, 1015-1023.

6. Wheeler, J.A.; Hermanutz, L.; Marino, P.M. Feathermoss seedbeds facilitate black spruce seedling recruitment in the forest-tundra ecotone (Labrador, Canada). Oikos 2011, 120, 1263-1271.

7. Zackrisson, O.; Dahlberg, A.; Norberg, G.; Nilsson, M.-C.; Jäderlund, A. Experiments on the effects of water availability and exclusion of fungal hyphae on nutrient uptake and establishment of Pinus sylvestris seedlings in carpets of the moss Pleurozium schreberi. Ecoscience 1998, 5, 77-85.

8. Weber, M.G.; van Cleve, K. Nitrogen transformations in feather moss and forest floor layers of interior Alaska black spruce ecosystems. Can. J. For. Res. 1984, 14, 278-290.

9. Nilsson, M.-C.; Steijlen, I.; Zackrisson, O. Time-restricted seed regeneration of Scots pine in sites dominated by feather moss after clear-cutting. Can. J. For. Res. 1996, 26, 945-953.

10. Simard, M.-J.; Bergeron, Y.; Sirois, L. Conifer seedling recruitment in a southeastern Canadian boreal forest: The importance of substrate. J. Veg. Sci. 1998, 9, 575-582.

11. Blok, D.; Heijmans, M.M.P.D.; Schaepman-Strub, G.; van Ruijven, J.; Parmentier, F.J.W.; Maximov, T.C.; Berendse, F. The cooling capacity of mosses: Controls on water and energy fluxes in a Siberian tundra site. Ecosystems 2011, 14, 1055-1065.

12. Oleskog, G.; Sahlen, K. Effects of seedbed substrate on moisture conditions and germination of Scots pine (Pinus sylvestris) seeds in a mixed conifer stand. New For. 2000, 20, 119-133.

13. Soudzilovskaia, N.A.; Bodegom, P.M.; Cornelissen, J.H. Dominant bryophyte control over high-latitude soil temperature fluctuations predicted by heat transfer traits, field moisture regime and laws of thermal insulation. Funct. Ecol. 2013, 27, 1442-1454.

14. Jackson, B.G.; Martin, P.; Nilsson, M.-C.; Wardle, D.A. Response of feather moss associated $\mathrm{N}_{2}$ fixation and litter decomposition to variations in simulated rainfall intensity and frequency. Oikos 2011, 120, 570-581.

15. Bay, G.; Nahar, N.; Oubre, M.; Whitehouse, M.J.; Wardle, D.A.; Zackrisson, O.; Nilsson, M.C.; Rasmussen, U. Boreal feather mosses secrete chemical signals to gain nitrogen. New Phytol. 2013, 200, 54-60.

16. Berg, A.; Danielsson, Å.; Svensson, B.H. Transfer of fixed-N from $\mathrm{N}_{2}$-fixing cyanobacteria associated with the moss Sphagnum riparium results in enhanced growth of the moss. Plant Soil 2013, 362, 271-278.

17. Schmalholz, M.; Hylander, K. Succession of bryophyte assemblages following clear-cut logging in boreal spruce-dominated forests in south-central Sweden-Does retrogressive succession occur? Can. J. For. Res. 2009, 39, 1871-1880. 
18. Palviainen, M.; Finer, L.; Mannerkoski, H.; Piirainen, S.; Starr, M. Responses of ground vegetation species to clear-cutting in a boreal forest: Aboveground biomass and nutrient contents during the first 7 years. Ecol. Res. 2005, 20, 652-660.

19. Donath, T.W.; Eckstein, R.L. Effects of bryophytes and grass litter on seedling emergence vary by vertical seed position and seed size. Plant Ecol. 2010, 207, 257-268.

20. Soudzilovskaia, N.A.; Graae, B.J.; Douma, J.C.; Grau, O.; Milbau, A.; Shevtsova, A.; Wolters, L.; Cornelissen, J.H.C. How do bryophytes govern generative recruitment of vascular plants? New Phytol. 2011, 190, 1019-1031.

21. Elumeeva, T.G.; Soudzilovskaia, N.A.; During, H.J.; Cornelissen, J.H.C. The importance of colony structure versus shoot morphology for the water balance of 22 subarctic bryophyte species. J. Veg. Sci. 2011, 22, 152-164.

22. Michel, P.; Lee, W.G.; During, H.J.; Cornelissen, J.H.C. Species traits and their non-additive interactions control the water economy of bryophyte cushions. J. Ecol. 2012, 100, 222-231.

23. Hájek, T.; Vicherová, E. Desiccation tolerance of Sphagnum revisited: A puzzle resolved. Plant Biol. 2014, 16, 765-773.

24. Proctor, M.C.; Oliver, M.J.; Wood, A.J.; Alpert, P.; Stark, L.R.; Cleavitt, N.L.; Mishler, B.D. Desiccation-tolerance in bryophytes: A review. Bryologist 2007, 110, 595-621.

25. Jentsch, A.; Beierkuhnlein, C. Research frontiers in climate change: Effects of extreme meteorological events on ecosystems. Comptes Rendus Geosci. 2008, 340, 621-628.

26. Lindo, Z.; Nilsson, M.C.; Gundale, M.J. Bryophyte-cyanobacteria associations as regulators of the northern latitude carbon balance in response to global change. Glob. Chang. Biol. 2013, 19, 2022-2035.

27. Chapin III, F.; Oechel, W.; van Cleve, K.; Lawrence, W. The role of mosses in the phosphorus cycling of an Alaskan black spruce forest. Oecologia 1987, 74, 310-315.

28. Lindo, Z.; Gonzalez, A. The bryosphere: An integral and influential component of the earth's biosphere. Ecosystems 2010, 13, 612-627.

29. Aerts, R.; Chapin III, F.S. The mineral nutrition of wild plants revisited: A re-evaluation of processes and patterns. Adv. Ecol. Res. 1999, 30, 1-67.

30. Parker, W.C.; Watson, S.R.; Cairns, D.W. The role of hair-cap mosses (Polytrichum spp.) in natural regeneration of white spruce (Picea glauca (moench) voss). For. Ecol. Manag. 1997, 92, $19-28$.

31. Zamfir, M. Effects of bryophytes and lichens on seedling emergence of alvar plants: Evidence from greenhouse experiments. Oikos 2000, 88, 603-611.

32. Wardle, D.A.; Lagerström, A.; Nilsson, M.C. Context dependent effects of plant species and functional group loss on vegetation invasibility across an island area gradient. J. Ecol. 2008, 96, 1174-1186.

33. Heijmans, M.M.P.D.; Arp, W.J.; Chapin, F.S. Controls on moss evaporation in a boreal black spruce forest. Glob. Biogeochem. Cycles 2004, 18, 1-8.

34. IPCC. Climate Change 2007: The Physical Science Basis Contribution of Working Group I to the Fourth Assessment; Cambridge University Press: Cambridge, UK, 2007; p. 996.

35. May, W. Potential future changes in the characteristics of daily precipitation in Europe simulated by the HIRHAM regional climate model. Clim. Dyn. 2008, 30, 581-603. 
36. Schlyter, P.; Stjernquist, I.; Bärring, L.; Jönsson, A.M.; Nilsson, C. Assessment of the impacts of climate change and weather extremes on boreal forests in northern Europe, focusing on Norway spruce. Clim. Res. 2006, 31, 75-84.

37. Rixen, C.; Mulder, C.P. Improved water retention links high species richness with increased productivity in arctic tundra moss communities. Oecologia 2005, 146, 287-299.

38. Gundale, M.J.; Nilsson, M.; Bansal, S.; Jaderlund, A. The interactive effects of temperature and light on biological nitrogen fixation in boreal forests. New Phytol. 2012, 194, 453-463.

39. Callaghan, T.V.; Collins, N.J.; Callaghan, C.H. Photosynthesis, growth and reproduction of Hylocomium splendens and Polytrichum commune in Swedish lapland. Strategies of growth and population dynamics of tundra plants 4 . Oikos 1978, 31, 73-88.

40. Gustafsson, L.; Hallingbäck, T. Bryophyte flora and vegetation of managed and virgin coniferous forests in south-west Sweden. Biol. Conserv. 1988, 44, 283-300.

41. Fenton, N.J.; Bergeron, Y. Facilitative succession in a boreal bryophyte community driven by changes in available moisture and light. J. Veg. Sci. 2006, 17, 65-76.

42. Wern, L. Luftfuktighet, Variationer i Sverige; SMHI: Norrköping, Sweden, 2013; p. 68.

43. DeLuca, T.H.; Zackrisson, O.; Nilsson, M.C.; Sellstedt, A. Quantifying nitrogen-fixation in feather moss carpets of boreal forests. Nature 2002, 419, 917-920.

44. Gundale, M.J.; From, F.; Bach, L.H.; Nordin, A. Anthropogenic nitrogen deposition in boreal forests has a minor impact on the global carbon cycle. Glob. Chang. Biol. 2014, 20, 276-286.

45. Dehlin, H.; Nilsson, M.-C.; Wardle, D.A.; Shevtsova, A. Effects of shading and humus fertility on growth, competition, and ectomycorrhizal colonization of boreal forest tree seedlings. Can. J. For. Res. 2004, 34, 2573-2586.

46. Jeschke, M.; Kiehl, K. Effects of a dense moss layer on germination and establishment of vascular plants in newly created calcareous grasslands. Flora 2008, 203, 557-566.

47. O’Donnell, J.A.; Romanovsky, V.E.; Harden, J.W.; McGuire, A.D. The effect of moisture content on the thermal conductivity of moss and organic soil horizons from black spruce ecosystems in interior Alaska. Soil Sci. 2009, 174, 646-651.

48. Økland, R.H.; Økland, T. Population biology of the clonal moss Hylocomium splendens in Norwegian boreal spruce forests. II. Effects of density. J. Ecol. 1996, 84, 63-69.

49. Castro, J. Seed mass versus seedling performance in Scots pine: A maternally dependent trait. New Phytol. 1999, 144, 153-161.

50. Zackrisson, O.; Nilsson, M.-C.; Dahlberg, A.; Jäderlund, A. Interference mechanisms in conifer-ericaceae-feathermoss communities. Oikos 1997, 78, 209-220.

51. Kellomäki, S. Book 2: Forest Resources and Sustainable Management; Fapet Oy: Helsinki, Finland, 1998.

52. Ohlson, M.; Zackrisson, O. Tree establishment and microhabitat relationships in north Swedish peatlands. Can. J. For. Res. 1992, 22, 1869-1877.

53. Kuuluvainen, T.; Juntunen, P. Seedling establishment in relation to microhabitat variation in a windthrow gap in a boreal Pinus sylvestris forest. J. Veg. Sci. 1998, 9, 551-562.

54. Gornall, J.L.; Woodin, S.J.; Jonsdottir, I.S.; van der Wal, R. Balancing positive and negative plant interactions: How mosses structure vascular plant communities. Oecologia 2011, 166, 769-782. 
55. Pedersen, B.; Hanslin, H.M.; Bakken, S. Testing for positive density-dependent performance in four bryophyte species. Ecology 2001, 82, 70-88.

56. Lavoie, M.; Paré, D.; Bergeron, Y. Relationships between microsite type and the growth and nutrition of young black spruce on post-disturbed lowland black spruce sites in eastern Canada. Can. J. For. Res. 2007, 37, 62-73.

57. Jackson, B.G.; Nilsson, M.-C.; Wardle, D.A. The effects of the moss layer on the decomposition of intercepted vascular plant litter across a post-fire boreal forest chronosequence. Plant Soil 2013, 367, 199-214.

58. Gundale, M.J.; Deluca, T.H.; Nordin, A. Bryophytes attenuate anthropogenic nitrogen inputs in boreal forests. Glob. Chang. Biol. 2011, 17, 2743-2753.

59. Fenton, N.J.; Bergeron, Y.; Pare, D. Decomposition rates of bryophytes in managed boreal forests: Influence of bryophyte species and forest harvesting. Plant Soil 2010, 336, 499-508.

(C) 2014 by the authors; licensee MDPI, Basel, Switzerland. This article is an open access article distributed under the terms and conditions of the Creative Commons Attribution license (http://creativecommons.org/licenses/by/3.0/). 